\title{
Ethnobotanical uses, phytochemistry and biological activities of Clerodendrum paniculatum L. (Lamiaceae): A comprehensive review
}

\author{
Prashith Kekuda T.R. ${ }^{{ }^{*}}$, Sudharshan S.J. ${ }^{2}$ \\ ${ }^{1}$ Department of Microbiology, S.R.N.M.N College of Applied Sciences, N.E.S campus, Balraj Urs Road, Shivamogga-577201, \\ Karnataka, India \\ ${ }^{2}$ Department of Biochemistry and Molecular Biology, School of Life Sciences, Pondicherry University, Puducherry, India
}

\begin{abstract}
Clerodendrum L. is an important genus in the family Lamiaceae in terms of its medicinal values and pharmacological properties. The genus comprises of more than 500 species distributed worldwide. In this review, we present an updated information on ethnobotanical uses, phytochemistry and biological activities of Clerodendrum paniculatum L. (Lamiaceae). The plant is one the most spectacular Clerodendrum species and is grown commonly for ornamental purpose. The plant is reported to have ethnomedicinal importance as the plant is used as remedy for ailments and disorders such as wounds, typhoid, snakebite, jaundice, giddiness, malaria, anemia and hemorrhoids. Various phytochemicals such as rutin, quercetin, $\beta$-sitosterol, $\beta$-amyrin, lupeol, oleanolic aldehyde acetate, stigmasta-4,25-dien-3-one, and (3 $\beta$ )-stigmasta-4,22,25-trien-3-ol have been identified in $C$. paniculatum. The plant is shown to exhibit biological activities such as antimicrobial, antioxidant, anthelmintic, anti-inflammatory, antimutagenic, cytotoxic, hypolipidemic, insecticidal and anti-ageing activity.
\end{abstract}

Keywords: Clerodendrum paniculatum L., Ethnobotanical, Traditional, Phytochemicals, Biological activities

Article Info: Received 21 Aug, 2018; Review Completed 24 Sep 2018; Accepted 25 Sep 2018; Available online 15 Oct 2018

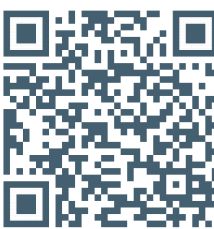

Cite this article as:

Prashith Kekuda TR, Sudharshan SJ, Ethnobotanical uses, phytochemistry and biological activities of Clerodendrum paniculatum L. (Lamiaceae): A comprehensive review, Journal of Drug Delivery and Therapeutics. 2018; 8(5-s):28-34 DOI: http://dx.doi.org/10.22270/jddt.v8i5-s.1930

Dr. Prashith Kekuda T.R, Department of Microbiology, S.R.N.M.N College of Applied Sciences, N.E.S campus, Balraj Urs Road, Shivamogga-577201, Karnataka, India

\section{INTRODUCTION}

Since ancient time human beings depend on plants for meeting various daily needs such as food, medicine and for construction and other purposes. Plants are considered as an integral part of daily life. An estimate highlights that around $80 \%$ of individuals in developing countries rely on plant based medicines for their primary healthcare. Plant based medicines are gaining much importance nowadays because of some drawbacks that are associated with the use of modern medicines. Indigenous systems of medicines widely employ plants as a remedy for dreadful ailments. ${ }^{1-5}$ The genus Clerodendrum L., belonging to the family Lamiaceae (previously placed in Verbenaceae, now included correctly in Lamiaceae based on phylogenetic data), comprises of several species $(>500)$ that occurs in tropical and subtropical regions worldwide. Several species of the genus are known to have medicinal values and widely used in different parts of the world. ${ }^{6-10}$ The study of Melapu et al. ${ }^{9}$ showed a significant correlation between phylogeny, chemical diversity and biological activities of the genus Clerodendrum $\mathrm{L}$.

Clerodendrum paniculatum L. (Kingdom: Plantae; Order: Lamiales; Family: Lamiaceae) is a shrub and is commonly known as pagoda flower. The species was first described by Swedish botanist Linnaeus. The species epithet is because of the large 'paniculate' clusters of flowers. It is often cultivated in garden as ornamental plant due its showy orange red to scarlet colored flowers in terminal panicles. The plant is 
distributed in countries such as India, Sri Lanka, Malaysia, Australia, China, Taiwan, Laos, Combodia, Vietnam, Indonesia, Bangladesh and many other Asian countries. It is known as Rathapushpa or Ratha hoo in Kannada., 11,12 The flowers are often visited by butterflies and the pollination process is mainly through butterflies. The plant is reported to have traditional medicinal values and is shown to exhibit a range of biological activities..$^{\mathbf{8} 13-16}$ In the present review, we present an updated information on the ethnomedicinal uses, phytochemistry and biological activities of $C$. paniculatum by an intensive literature survey carried out by referring standard flora, journals and online search engines viz. PubMed, ScienceDirect and Google Scholar.

\section{PLANT DESCRIPTION}

C. paniculatum is an erect, semi-woody shrub reaching a height of 1-2m (Figure 1). Leaves are simple, large, opposite, up to $30 \mathrm{~cm}$ in diameter. Leaves are membranous, cordate-ovate, 3-7 lobed (lobes shallow), margins minutely denticulate, glandular beneath and petiole is up to $30 \mathrm{~cm}$ long with acuminate apex. Flowers are in large terminal panicles. Calyx is red to orange-red in color and divided nearly to the base. Corolla are orange-red to scarlet with slender tube which is up to $2 \mathrm{~cm}$ long and the lobes are approximately $7 \mathrm{~mm}$ long. Flowering occurs more or less throughout year. Fruit is a drupe, globose, bluish-black in color and approximately $1 \mathrm{~cm}$ across. ${ }^{12,17,18}$
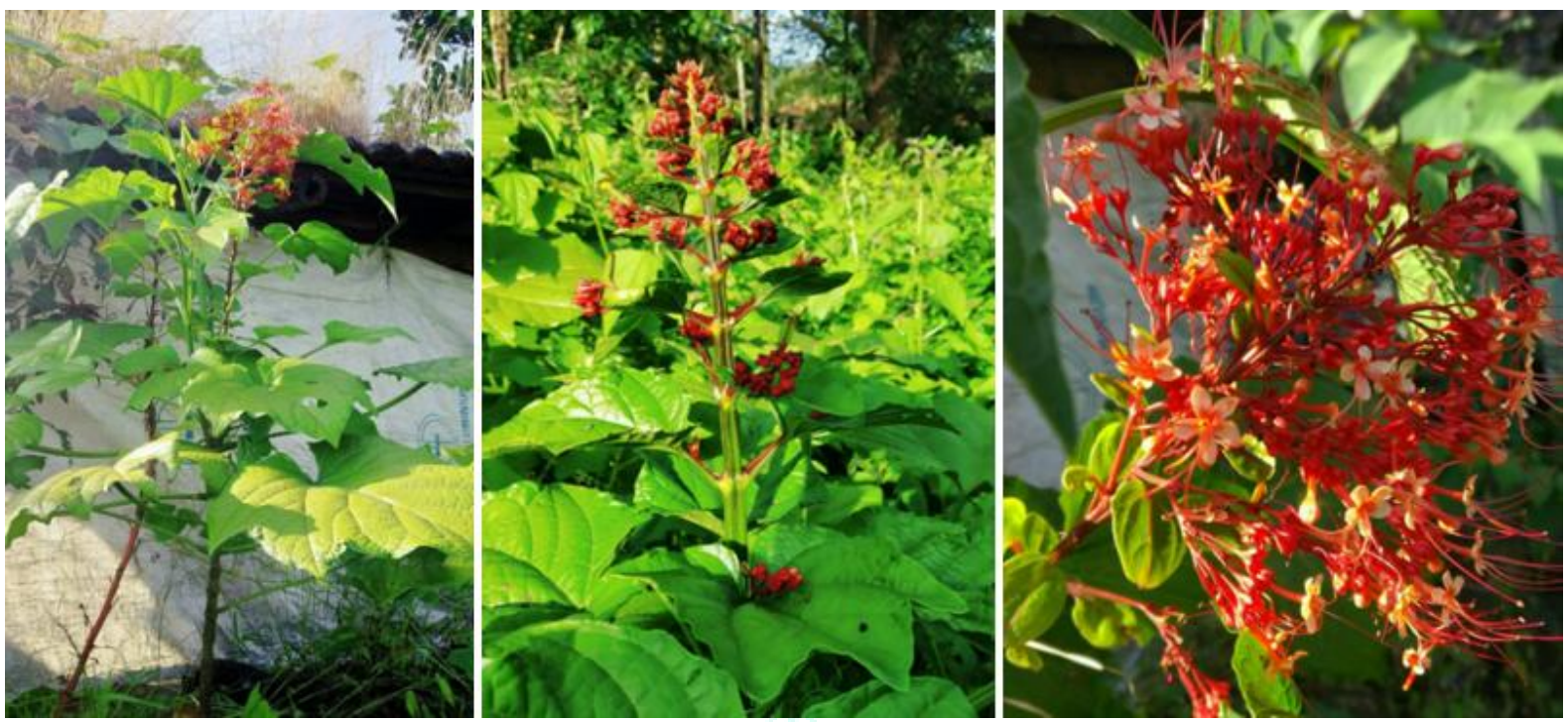

Figure 1: Clerodendrum paniculatum $\mathbf{L}$.

\section{ETHNOMEDICINAL USES OF C. PANICULATUM}

Various species of the genus Clerodendrum have been widely used ethnobotanically as ornamental plants as well as for treating several diseases and disorders. ${ }^{\mathbf{1 4 , 1 9 - 2 3}}$ The plant $C$. paniculatum is reported to have some ethnobotanical uses as ornamental as well as medicinal plant in some parts of the world. The plant is used traditionally in countries such as India, China and Japan for treating rheumatism, ulcer, neuralgia, inflammation, and wounds. It is used as anti-inflammatory and antipyretic drug in traditional Thai medicine. ${ }^{\mathbf{2 4}} C$. paniculatum is classified as ornamental species in Lao PDR. The plant is also reported as medicinal. ${ }^{23}$ In Lombok, Indonesia, the plant is used to treat sore eyes. ${ }^{25}$ C. paniculatum is commonly used in herbal bath preparation by Yunnanese group in Thailand. ${ }^{2}$ The Nicobarese of Nancowry group of Islands in Andaman and Nicobar uses the plant traditionally for treating wounds, jaundice, body ache, snake bite and giddiness. ${ }^{14}$ More detail on ethnomedicinal uses of $C$. paniculatum is presented in Table 1.

Table 1: Ethnomedicinal uses of $C$. paniculatum

\begin{tabular}{|c|c|c|c|}
\hline Geographical area & Part & Use & Reference \\
\hline Cherpu block, Kerala, India & Leaves & Treatment of wounds & $\begin{array}{l}\text { Vijayan and } \\
\text { Gopakumar }^{26}\end{array}$ \\
\hline Dhalai district, Tripura, India & Roots & Treatment of typhoid & Shil and Choudhury $^{27}$ \\
\hline $\begin{array}{l}\text { Ri-Bhoi district, Meghalaya, } \\
\text { India }\end{array}$ & Leaves & $\begin{array}{l}\text { Treatment of anemia, liver complaints } \\
\text { and for purification of blood }\end{array}$ & Sen et $a l^{28}$ \\
\hline Northern Thailand & Flowers and leaves & Treatment of hemorrhoids & Khuankaew et al. ${ }^{4}$ \\
\hline Southern Nigeria & Leaves and roots & Treatment of malaria & Iyamah and Idu $^{15}$ \\
\hline
\end{tabular}




\section{PHYTOCHEMISTRY OF C. PANICULATUM}

Members of Clerodendrum L. are shown to contain myriad of phytochemicals and over 280 phytochemicals have been described from different Clerodendrum species. ${ }^{\mathbf{6 , 1 0 , 2 9 , 3 0}}$ Standard phytochemical tests, chromatographic and spectral methods have been used to identify phytochemicals in C. paniculatum. Chemicals viz. (24s)ethylcholesta-5,22,25-triene-3 $\beta$ ol, $\beta$-amyrin and $\beta$-sitosterol were obtained from the roots of $C$. paniculatum. ${ }^{31}$ Phytoconstituents viz. alkaloids, coumarins, flavonoids, glycosides, phenols, phytosterols, saponins, terpenoids have been detected in the leaves of C. paniculatum by standard phytochemical tests. ${ }^{7}$ The presence of terpenes, flavonoids, tannins, alkaloids, phenolic acid, sterols, and glycosides in the leaf extract was detected in a study by Joseph et $a l^{32}$ More information on the phytochemicals in $C$. paniculatum is presented in Table 2. Figure 2 shows the structures of some compounds that have been identified in $C$. paniculatum.

Table 2: Phytochemicals in C. paniculatum L.

\begin{tabular}{|c|c|c|}
\hline Part & Phytochemical & Reference \\
\hline Leaves & Poriferasta-5.22E.25-trien-3 $\beta$-ol & Musa et $a l .^{33}$ \\
\hline Root & Quercetin & Leena and Aleykutty ${ }^{34}$ \\
\hline Root & $\begin{array}{l}\beta \text {-sitosterol; lupeol; oleanolic aldehyde acetate; } \\
(22 \mathrm{E}) \text {-stigmasta-4,22,25-trien-3-one; stigmasta-4,25-dien-3-one; and }(3 \beta) \text { - } \\
\text { stigmasta-4,22,25-trien-3-ol }\end{array}$ & Phontree et al. ${ }^{13}$ \\
\hline Leaves & Tannins, phenols, sterols & Praveen et al. ${ }^{35}$ \\
\hline Root & Phenolic compounds, flavonoids, saponins, tannins & Leena et $a l .^{36}$ \\
\hline Leaves & Rutin and quercetin & Krishnan et al. $^{37}$ \\
\hline
\end{tabular}

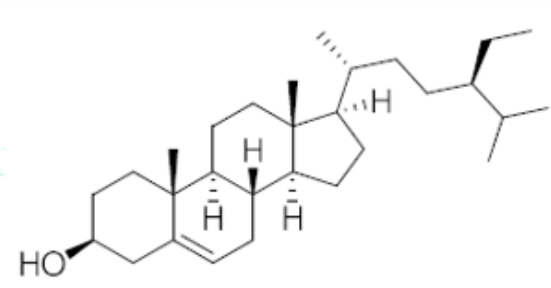

$\beta$-sitosterol

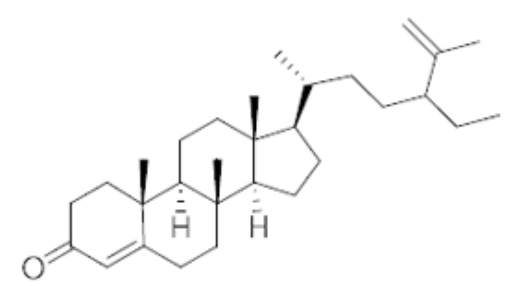

Stigmasta-4,25-dien-3-one

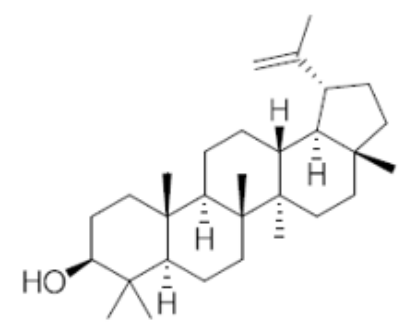

Lupeol

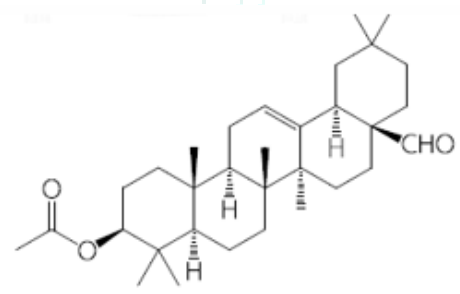

Oleanolic aldehyde acetate

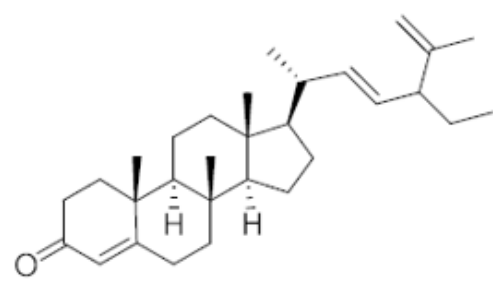

(22E)-stigmasta-4,22,25-trien-3-one

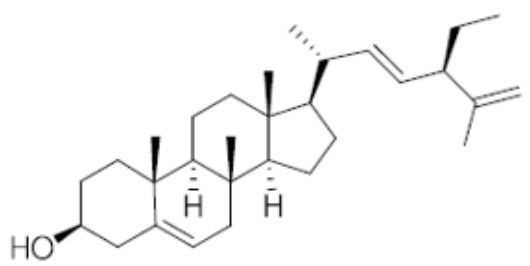

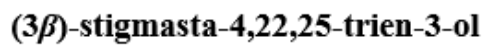

Figure 2: Some compounds identified in C. paniculatum ${ }^{38}$

\section{BIOLOGICAL ACTIVITIES OF C. PANICULATUM}

Clerodendrum species are versatile with respect to biological or pharmacological activities they display. It is shown from several studies that crude extracts and purified compounds from Clerodendrum species exhibit a range of biological activities. ${ }^{\mathbf{1 0 2 4 , 3 8 , 3 9 , 4 0}} \mathrm{A}$ number of studies, which were carried out on $C$. paniculatum, highlighted its potential to exhibit a range of biological activities such as antimicrobial, antioxidant, insecticidal, hypolipidemic, anti-inflammatory, anthelmintic, 
antimutagenic, cytotoxic and anti-ageing activities. A brief description on the biological activities of $C$. paniculatum is presented below.

\section{Antioxidant activity}

Hafiz et al. ${ }^{\mathbf{4 1}}$ investigated scavenging of DPPH radicals by ethanolic extract obtained from leaves of $C$. paniculatum. The extract revealed concentration dependent scavenging of radicals with an $\mathrm{IC}_{50}$ value of $27.73 \mu \mathrm{g} / \mathrm{ml}$. John et $a .^{\mathbf{4 2}}$ revealed the potential of ethanol extract of roots of $C$. paniculatum to exhibit antioxidant activity by DPPH and ABTS radical scavenging assays. Arun et al. ${ }^{\mathbf{4 3}}$ revealed the antioxidant potential of methanolic extract of leaf and root of $C$. paniculatum as evaluated by DPPH radical, hydroxyl radical and superoxide radical scavenging assays and reducing power assay. Krishnan et al. ${ }^{\mathbf{3 7}}$ revealed potent antioxidant activity of aqueous and methanolic extract of $C$. paniculatum as evaluated by reducing power assay.

\section{In vitro anti-inflammatory activity}

Different solvent extracts of $C$. paniculatum leaves were tested for in vitro anti-inflammatory potential by human red blood cell membrane stabilization method. Solvent extracts showed concentration dependent activity with marked activity being exhibited by petroleum ether and chloroform extracts. ${ }^{32}$ The ethanolic extract of $C$. paniculatum root was screened for in vitro antiinflammatory activity on the basis of evaluation of nitric oxide, tumor necrosis factor (TNF- $\alpha$ ) and prostaglandin E2 in murine macrophage J774A.1 cells stimulated by lipopolysaccharide. The root extract was shown to significantly inhibit LPS induced nitric oxide, TNF- $\alpha$ and prostaglandin E2 production in macrophage cells. ${ }^{\mathbf{2 4}}$

\section{In vivo anti-inflammatory activity}

Hafiz et $a l .^{41}$ studied anti-inflammatory potential of ethanolic extract obtained from leaves of $C$. paniculatum by paw edema and granuloma cotton pellet method in rats. In both the assays, the leaf extract showed concentration dependent activity. A significant anti-inflammatory activity was observed at dose $50 \mathrm{mg} / \mathrm{kg}$ body weight. The study by Joseph et al. ${ }^{32}$ also revealed anti-inflammatory activity of petroleum ether and chloroform extracts of $C$. paniculatum leaves as evaluated by carrageenan induced paw edema model in male Wistar rats.

\section{Anthelmintic activity}

Praveen et $a l .{ }^{44}$ evaluated anthelmintic activity of various solvent extracts of $C$. paniculatum leaves in terms of time taken for paralysis and death of the earthworm Eudrilus Eugenia. Methanol extract showed significant activity as it took less time to cause paralysis and death of worms. Aqueous extract was not active while chloroform and ethyl acetate extracts revealed less anthelmintic activity.

\section{Mutagenic and antimutagenic activity}

Ethanolic extract of $C$. paniculatum root was investigated for mutagenic and antimutagenic activity by Ames test using Salmonella typhimurium strain
TA98 and S. typhimurium strain TA100. The extract was not mutagenic. Besides, the extract was shown to inhibit mutagenicity of nitrite treated 1-aminopyrene on both strains of $S$. typhimurium. ${ }^{24}$

\section{Cytotoxic/anticancer activity}

Anticancer activity of ethanolic extract of $C$. paniculatum roots was assessed using tumor model in mice. The administration of extract in animals, although increased the mean survival time and reduced the tumor volume, the anticancer effect observed was not significant when compared to cisplatin. ${ }^{\mathbf{4 2}}$ Compounds viz. Oleanolic aldehyde acetate and (3 $\beta)$-stigmasta4,22,25-trien-3-ol isolated from the dichloromethane extract of root showed cytotoxic activity against the $\mathrm{KB}$ cell line with an $\mathrm{IC}_{50}$ value of $9.58 \mu \mathrm{g} / \mathrm{mL}$ and $13.14 \mu \mathrm{g} / \mathrm{mL}$, respectively. ${ }^{13}$ Oleanolic aldehyde acetate and (3 $\beta)$-stigmasta-4,22,25-trien-3-ol also exhibited cytotoxicity against $\mathrm{HeLa}$ cells with $\mathrm{IC}_{50}$ values of $31.43 \mu \mathrm{g} / \mathrm{mL}$ and $28.52 \mu \mathrm{g} / \mathrm{mL}$, respectively. ${ }^{38}$ The study of Praveen et $a .^{35}$ revealed dose dependent cytotoxic effect of solvent extracts of $C$. paniculatum leaves in terms of mortality of brine shrimp larvae. Petroleum ether extract showed potent activity than methanol extract. The study carried out by John et al. ${ }^{\mathbf{4 5}}$ showed a dose dependent in vitro cytotoxicity of various solvent extracts of $C$. paniculatum against cell lines viz. HeLa, HepG2, and MCF7 as evaluated by trypan blue exclusion test, MTT assay and SRB assay. Sundaraganapathy and Leena ${ }^{\mathbf{4 6}}$ showed anticancer activity of ethanolic extract of root of $C$. paniculatum and phytosome formulated from root extracts against DLA induced tumor in Swiss albino mice. Administration of root extract and phytosome resulted in reduction in tumor volume and tumor weight, an increase in mean survival time and restoration of haematological parameters indicating anticancer potential.

\section{Anti-ageing activity}

The potential of polyherbal based cream formulations containing $C$. paniculatum leaf extract to reveal skin anti-ageing benefits was investigated by Krishnan et $a l{ }^{47}$ The formulation was cytotoxic to least extent and caused an increase in the collagen content in human dermal fibroblast indicating skin anti-ageing property. The formulation was also found to upregulate CollagenI gene expression. Krishnan et al. ${ }^{\mathbf{3 7}}$ also revealed antiageing activity of methanol and aqueous extract of $C$. paniculatum leaves in human dermal fibroblast.

\section{Antimicrobial activity}

Various solvent extracts of leaves of $C$. paniculatum were tested for antibacterial activity against gram negative bacteria viz. Escherichia coli, Salmonella newport and Vibrio parahemolyticus by agar well diffusion assay. All extracts were effective in inhibiting $V$. parahemolyticus whereas petroleum ether and chloroform extracts were ineffective against $E$. coli and $S$. newport. ${ }^{48}$ Methanol extract of $C$. paniculatum was shown to cause inhibitory activity against antibiotic resistant strains of Escherichia coli and Klebsiella pneumoniae. Among bacteria, E. coli was inhibited to 
slightly higher extent when compared to $K$. pneumoniae. $^{\mathbf{4 9}}$ Abdullah et al. $^{\mathbf{5 0}}$ screened methanol extract of leaves, flowers and stem of $C$. paniculatum against Bacillus subtilis and $E$. coli by disc diffusion method. The extracts were effective against $B$. subtilis while no inhibitory activity of extracts was observed against E. coli. Among extracts, leaf extract showed slightly higher inhibition of B. subtilis. The study by Praveen et al. $^{35}$ revealed the potential of chloroform and methanol extract of leaves of $C$. paniculatum to inhibit Candida albicans, Staphylococcus aureus and Pseudomonas aeruginosa. Leena and Aleykutty ${ }^{51}$ revealed dose dependent antibacterial activity of ethanol extract of $C$. paniculatum root against $B$. subtilis, $E$. coli, K. pneumoniae and $S$. aureus. The study of Othman et $a{ }^{\mathbf{5 2}}$ revealed slight inhibitory activity of hexane, ethyl acetate and ethanol extract of aerial parts of $C$. paniculatum against Bacillus subtilis.

\section{Hypolipidemic activity}

Hypolipidemic activity of leaf extract of $C$. paniculatum was investigated by Selvin and Rakhi ${ }^{\mathbf{5 3}}$ in male Wistar rats fed with high fat diet. Administration of extract was shown to significantly decrease the level of lipid profile and lipoprotein levels. A significant increase in the HDL level and a decrease in body weight was observed in extract treated animals.

\section{Insecticidal activity}

Crude ethanolic leaf extracts of various Clerodendrum species including $C$. paniculatum were screened for insecticidal activity against Spodoptera litura and Helicoverpa armigera by antifeedant assay, growth inhibitory assay and larval mortality assay. The extract exhibited dose dependent insecticidal activity, however,

\section{REFERENCES}

1. Ssegawa P, Kasenene JM Medicinal plant diversity and uses in the Sango bay area, Southern Uganda, J Ethnopharmacol, 2007; 113:521-540.

2. Panyaphu K, On TV, Sirisa-ard P, Srisa-nga P, Chansakaow S, Nathakarnkitkul S, Medicinal plants of the Mien (Yao) in Northern Thailand and their potential value in the primary healthcare of postpartum women, J Ethnopharmacol, 2011; 135:226-237.

3. Hemalatha M, Thirumalai T, Saranya R, Elumalai EK, David E, A review on antimicrobial efficacy of some traditional medicinal plants in Tamilnadu, J Acute Dis, 2013; 2(2):99105.

4. Khuankaew S, Srithi K, Tiansawat P, Jampeetong A, Inta A, Wangpakapattanawong $\mathrm{P}$, Ethnobotanical study of medicinal plants used by Tai Yai in Northern Thailand, J Ethnopharmacol, 2014; 151:829-838.

5. Bhat P, Hegde GR, Hegde G, Mulgund GS, Ethnomedicinal plants to cure skin diseases - An account of the traditional knowledge in the coastal parts of Central Western Ghats, Karnataka, India, J Ethnopharmacol, 2014; 151:493-502.

6. Shrivastava N, Patel T, Clerodendrum and healthcare: An overview - Part II Phytochemistry and Biotechnology, Medicinal and Aromatic Plant Science and Biotechnology, 2007; 1(2):209-223.

7. Florence AR, Joselin J, Jeeva S, Intra-specific variation of bioactive principles in select members of the genus the activity observed was moderate when compared to other Clerodendrum species. ${ }^{\mathbf{5 4}}$

\section{Induction of systemic resistance in plant}

In a study by Musa et $a l .{ }^{33}$ a compound identified as Poriferasta-5.22E.25-trien-3 $\beta$-ol isolated from leaves of C. paniculatum was shown to be an inducer of systemic resistance in red chilli (Capsicum annuum L) against infection caused by cucumber mosaic virus. The compound displayed an inhibitory activity of $82 \%$ at 300ppm.

\section{CONCLUSIONS}

C. paniculatum is one of the important species of the genus Clerodendrum L. distributed in many Asian countries. A detailed literature survey conducted in this study revealed the importance of $C$. paniculatum in terms of its medicinal and pharmacological potential. The details obtained from the ethnomedicinal and pharmacological activities can be helpful in the development of newer and safer formulations containing the plant that can be effectively used in the treatment of several diseases and disorders. Further studies can be undertaken in order to isolate active principles from the plant and to determine their possible therapeutic potential.

\section{ACKNOWLEDGEMENTS}

Authors thank Principal, S.R.N.M.N College of Applied Sciences and N.E.S, Shivamogga for the moral support provided. Authors also thank Ms. Srilakshmi N.S for providing photographs of the plant.

\section{Sources of funding: None}

Conflicts of interest: None declared

Clerodendrum L, J Chem Pharm Res, 2012; 4(11):49084914.

8. Kar P, Goyal AK, Das AP, Sen A, Antioxidant and pharmaceutical potential of Clerodendrum L.: An overview, Int J Green Pharm, 2014; 8(4):210-216.

9. Melapu VK, Joginipelli S, Naidu BVA, Darsey J, A comparative phylogenetic evaluation of chloroplast ITS sequences to analyze the bioactivity in medicinal plants: A case study of Clerodendrum plant genus (Lamiaceae), Austin J Comput Biol Bioinform, 2015; 2(1):1011.

10. Wang J, Luan F, He X, Wang Y, Li M, Traditional uses and pharmacological properties of Clerodendrum phytochemicals, J Tradit Complement Med, 2018; 8(1):2438.

11. Leeratiwong $\mathrm{C}$, Chantaranothai, $\mathrm{P}$, Paton AJ, A synopsis of the genus Clerodendrum L. (Lamiaceae) in Thailand, Tropical Natural History, 2011; 11(2):177-211.

12. Bhat GK, Flora of South Kanara (Dakshina Kannada and Udupi districts of Karnataka), Aakriti Prints, Mangalore, India, 2014

13. Phontree K, Sichaem J, Siripong P, Tip-pyang S, Chemical constituents of the roots of Clerodendrum paniculatum, Chem Nat Compd, 2014; 50(5):950-951.

14. Chander PM, Kartick C, Vijayachari P, Herbal medicine and healthcare practices among Nicobarese of Nancowry group 
of Islands - an indigenous tribe of Andaman and Nicobar Islands, Indian J Med Res, 2015; 141:720-744.

15. Iyamah PC, Idu M, Ethnomedicinal survey of plants used in the treatment of malaria in southern Nigeria, J Ethnopharmacol, 2015; 173:287-302.

16. Rajeswari NB, Jeyabalan D, Studies on biology and reproduction of butterflies (family: papilionidae) in Nilgiris Hills, Southern Western Ghats, India, Int J Adv Res Biol Sci, 2017; 4(2):1-11.

17. Punekar SA, Lakshminarasimhan P, Flora of Anshi national park, Western Ghats- Karnataka, Biosphere Publications, Pune, India, 2011.

18. Deori C, Roy DK, Talukdar SR, Pagag K, Sarma N, Diversity of the genus Clerodendrum Linnaeus (Lamiaceae) in Northeast India with special reference to Barnadi Wildlife Sanctuary, Assam, Pleione, 2013; 7(2):473-488.

19. Jadhav D, Ethnomedicinal plants used by Bhil tribe of Bibdod, Madhya Pradesh, Indian J Tradit Know, 2006; 5(2):263-267.

20. Rao DM, Rao UVUB, Sudharshanam G, Ethno-medicobotanical studies from Rayalaseema region of Southern Eastern Ghats, Andhra Pradesh, India, Ethnobotanical Leaflets, 2006; 10:198-207.

21. Jiji P, Ethnomedicinal uses of wild vegetables used by TaiShyam people of Sivasagar district, Assam, India, Int Res J Biol Sci, 2014; 3(11):63-65.

22. Singh PN, Gajurel PR, Rethy P, Ethnomedicinal value of traditional food plants used by the Zeliang tribe of Nagaland, Indian J Tradit Know, 2015; 14(2):298-305.

23. Park JH, Kang HS, Bang M, Cheng HC, Jin HY, Ahn TH, Bounithiphonh $\mathrm{C}$, Phongoudome C, Floristic inventory of vascular plant in Nam Ha National Biodiversity Conservation Area, Lao People's Democratic Republic, J Asia Pac Biodivers, 2018; 11:300-304.

24. Phuneerub P, Limpanasithikul W, Palanuvej C, Ruangrungsi $\mathrm{N}$, In vitro anti-inflammatory, mutagenic and antimutagenic activities of ethanolic extract of Clerodendrum paniculatum root, J Adv Pharm Technol Res, 2015; 6(2):48-52.

25. Hadi S, Bremner JB, Initial studies on alkaloids from Lombok medicinal plants, Molecules, 2001; 6:117-129.

26. Vijayan AS, Gopakumar S, Ethnobotany and shruby diversity in homegardens of Cherpu block, Kerala, India, Indian Forester, 2015; 141(2):211-214.

27. Shil S, Choudhury MD, Indigenous knowledge on healthcare practices by the Reang tribe of Dhalai district of Tripura, North East India, Ethnobotanical Leaflets, 2009; 13:775-790.

28. Sen S, Pathak SK, Suiam ML, Weed flora of tea plantations of Ri-Bhoi District of Meghalaya, India with a glimpse on its ethnobiological value, World Sci News, 2016; 56 82-96.

29. Tian J, Zhao Q, Zhang H, Lin Z, Sun H, New cleroindicins from Clerodendrum indicum, J Nat Prod, 1997; 60(8):766769.

30. Verma S, Gupta R, Comparative estimation of $\beta$-sitosterol in roots, leaves and flowers of Clerodendrum infortunatum $\mathrm{L}$, Int J Green Pharm, 2013; 7(2):131-135.

31. Joshi KC, Singh P, Mehra A, Chemical investigation of the roots of different Clerodendron species, Planta Med, 1979; 37:64-66.

32. Joseph J, Bindhu AR, Aleykutty NA, In vitro and in vivo antiinflammatory activity of Clerodendrum paniculatum Linn. leaves, Indian J Pharm Sci, 2013; 75(3):376-379.

33. Musa W, Hersanti, Zainuddin A, Tjokronegoro R, The poriferasta compound-5,22E,25-trien-3-o $\beta$ from Clerodendrum paniculatum leaf as inducer agent of systemic resistance on red chilli plant Capsicum annuum $\mathrm{L}$ from cucumber mosaic virus (CMV), Indo J Chem, 2009; $9(3): 479-486$

34. Leena PN, Aleykutty NA, Isolation and spectral identification of quercetin from the alcoholic root extract of Clerodendrum paniculatum Linn, Int J Pharma Sci Res, 2016; 7(1):47-50.

35. Praveen M, Radha K, Kumar HR, Padmaja V, Mathew A, Kumar AP, Preliminary Phytochemical, antimicrobial and toxicity studies on Clerodendrum paniculatum Linn leaves, Hygeia Journal of Drugs and Medicines, 2012; 4(1):41-50.

36. Leena PN, Aleykutty NA, Prasanth KG, Estimation of total phenolic and flavonoid content in alcoholic root extract of Clerodendron paniculatum by spectrophotometric method, Indo Am J Pharm Sci, 2016; 3(4):348-350.

37. Krishnan DR, Vijayakumar M, Varma SR, Ilavarasu A, Dhanabal SP, In vitro anti-skin ageing benefits of Clerodendrum paniculatum leaf extracts, World J Pharm Res, 2017; 6(7):1645-1657.

38. Phontree K, Chemical constituents and cytotoxicity from roots of Clerodendrum paniculatum, the stem bark of Walsura trichostemon and tuber of Butea superba, Ph.D thesis, Chulalongkorn University, Thailand, 2014.

39. Pushpavathi D, Shilpa M, Petkar T, Siddiqha A, Kekuda PTR, Evaluation of antifungal activity of some plants against seedborne fungi, Sch J Agric Vet Sci, 2017; 4(4):155-159.

40. Somwong P, Suttisri R, Cytotoxic activity of the chemical constituents of Clerodendrum indicum and Clerodendrum villosum roots, J Integr Med, 2018; 16(1):57-61.

41. Hafiz I, Rosidah, Silalahi J, Antioxidant and anti-inflammatory activity of pagoda leaves (Clerodendrum paniculatum L.) ethanolic extract in white male rats (Rattus novergicus), Int J PharmTech Res, 2016; 9(5):165-170.

42. John J, Mathew JA, Setty MM, free radical scavenging and anticancer activity of Clerodendron paniculatum, Pharmacologyonline, 2008; 3:730-743.

43. Arun PV, Sachin S, Suganyadevi P, Antioxidant potential of Clerodendrum paniculatum, J Pharm Res, 2011; 4(6):17961799.

44. Praveen M, Radha K, Padmaja V, William H, Ajithkumar P, In vitro anthelmintic activity of Clerodendrum paniculatum Linn leaves, Res J Pharm Biol Chem Sci, 2013; 4(2):321325 .

45. John J, Mathew JA, Sreedhara CS, Setty MM, In vitro anticancer study of Clerodendon paniculatum, Pharmacologyonline, 2010; 3:384-391.

46. Sundaraganapathy, Leena PN, Development and evaluation of anti-cancer activity of phytosome formulated from the root extract of Clerodendron Paniculatum Linn, International Journal of Pharmacognosy and Phytochemical Research, 2016; 8(11):1778-1781.

47. Krishnan DR, Kumar VKM, Varma SR, Babu UV, Dhanabal SP, Design and development of polyherbal based cream formulation with anti-skin ageing benefits, Int J Pharm Sci Res, 2017; 8(10):4147-4158.

48. Joseph J, Bindhu AR, Aleykutty NA, Antimicrobial activity of Clerodendrum paniculatum Linn. leaves, Int J Res Ayurveda Pharm, 2011; 2(3):1003-1004.

49. Shruthi G, Joyappa MP, Chandrashekhar S, Kollur SP, Prasad MNN, Prasad A, Shivamallu C, Bactericidal property of Clerodendrum paniculatum and Saraca asoka against multidrug resistant bacteria, restoring the faith in herbal medicine, Int J Pharm Sci Res, 2017; 8(9):3863-3871. 
50. Abdullah E, Raus RA, Jamal P, Extraction and evaluation of antibacterial activity from selected flowering plants, Am Med J, 2012; 3(1):27-32.

51. Leena PN, Aleykutty NA, Comparitive study on antibacterial activities of Clerodendron infortunatum Linn and Clerodendron paniculatum linn root extract, Int J Adv Pharm Biol Chem, 2012; 1(3):325-327.

52. Othman M, Genapathy S, Liew PS, Ch'ng QT, Loh HS, Khoo TJ, Wiart C, Ting KN, Search for antibacterial agents from Malaysian rainforest and tropical plants, Nat Prod Rec, 2011; 25(19):1857-1864
53. Selvin SCD, Rakhi AR, Evaluation of hypolipidemic effect of various extracts of whole plant of Clerodendrum paniculatum in rat fed with high fat diet, Eur $\mathbf{J}$ Biomed Pharm Sci, 2014; 1(1):87-96.

54. Jadhav GS, Devarshi AA, Yankanchi SR, Efficacy of certain Clerodendrum leaf crude extracts against cutworm, Spodoptera litura Fab and cotton bollworm, Helicoverpa armigera Hub, Journal of Entomology and Zoology Studies, 2016; 4(4):466-472. 